\title{
Wild-type oestrogen receptor beta (ER $\beta \mid$ ) mRNA and protein expression in Tamoxifen-treated post-menopausal breast cancers
}

\author{
PA O'Neill', MPA Davies', AM Shaaban², H Innes', A Torevell', DR Sibson' and CS Foster*,2 \\ 'Clatterbridge Cancer Research Trust, J.K. Douglas Laboratories, Clatterbridge Hospital, Bebington, Wirral, CH63 4JY, UK; ${ }^{2}$ Department of Cellular and \\ Molecular Pathology, University of Liverpool, L69 3GA, UK
}

This study has tested the hypothesis that comparison of protein and mRNA expression for ER $\alpha$ and ER $\beta$ I by human breast cancers provides novel information relating to the clinical and pathological characteristics of human breast cancers. Expression of ER $\alpha$ and $\mathrm{ER} \beta \mathrm{I}$ was identified in 167 invasive cancers from postmenopausal women treated only with endocrine therapy. The cohort included I 43 cases receiving only adjuvant Tamoxifen following surgery. ER $\alpha$ and $\operatorname{ER} \beta \mid$ expression was analysed by immunohistochemistry and reverse transcription RT-PCR and compared with clinical progression of individual cancers. ER $\alpha$ protein was closely associated with the corresponding RNA detected by RT-PCR (Chi-square, $P<0.00 \mathrm{I}$ ). In contrast, ER $\beta$ I protein and mRNA were inconsistent. Although an association was identified between ER $\alpha$ and $E R \beta$ mRNAs (Chi-square, $P<0.00 \mathrm{I}$ ) and between ER $\alpha$ protein and ER $\beta$ I mRNA (Chi-square, $P<0.027$ ), no association was identified for the $E R \alpha$ and $E R \beta \mid$ proteins detected by immunohistochemistry. $\mathrm{ER} \beta \mid$ was not associated with outcome. However, in the absence of $\mathrm{ER} \alpha, \mathrm{ER} \beta \mid$ protein expression was associated with elevated cell proliferation. There was a trend for the $\mathrm{ER} \beta \mid$ protein-positive cases to have a worse outcome, both within the group as a whole as well as within the ER $\alpha$-positive Tamoxifen-treated cases. This study has confirmed the hypothesis that expression of ER $\alpha$ is an important determinant of breast cancer progression, and has further demonstrated that $\mathrm{ER} \beta \mid$ may play a role in the response of breast cancers to endocrine therapy.

British Journal of Cancer (2004) 91, 1694- 1702. doi:I0.1038/sj.bjc.6602 I83 www.bjcancer.com

Published online 12 October 2004

(c) 2004 Cancer Research UK

Keywords: breast cancer; ER gene expression; tamoxifen; oestrogen receptor beta; tumour progression

Currently, $\mathrm{ER} \alpha$ expression is regarded as a reliable prognostic marker with which to predict the response of an individual breast cancer to hormone therapy (Pertschuk and Axiotis, 1999). However, up to $40 \%$ of breast tumours with positive ER $\alpha$ status do not respond to endocrine manipulation (Locker, 1998). The biological basis of this failure to respond is poorly understood, although modulated expression of $\operatorname{ER} \beta$ has been implicated. Unlike $\mathrm{ER} \alpha$, the antioestrogen-ER $\beta$ complex inhibits gene transcription when bound to oestrogen response elements (EREs), but acts as an agonist when bound to AP1 elements (Paech et al, 1997). Therefore, it is possible that antioestrogens may have agonistic effects in $\operatorname{ER} \beta$ positive breast tumours, resulting in a lack of efficacy of hormonal therapy. This hypothesis is supported by a small number of cases in which overexpression of ER $\beta$ RNA has been found in Tamoxifenresistant tumours $(n=9)$ when compared with a Tamoxifensensitive group $(n=8)$ (Speirs et al, 1999), but refuted by an immunohistochemical study (Mann et al, 2001) of $\mathrm{ER} \beta$ protein in a larger group $(n=118)$. Hitherto, only a limited number of studies have used ER $\beta$-specific antibodies (Jarvinen et al, 2000; Omoto et al, 2001; Saunders et al, 2002). These have been based on relatively

*Correspondence: Professor CS Foster, Department of Pathology, Duncan Building, Royal Liverpool University Hospital, Daulby Street, Liverpool, L69 3GA, UK; E-mail: csfoster@liverpool.ac.uk

Received 29 March 2004; revised 21 July 2004; accepted 17 August 2004; published online 12 October 2004 small numbers of unselected cases and do not all address the relationship of ER $\beta 1$ expression with patient outcome. Similarly, there are limited studies addressing the specific relationship of ER $\beta$ with endocrine therapy (Speirs et al, 1999; Mann et al, 2001; Saji et al, 2002). Hence, the present study has been restricted to an assessment of postmenopausal women receiving endocrine therapy, but no chemotherapy, in order to better address the likely impact of ER $\beta 1$ expression on response in this common clinical setting.

Recent development of reliable antibodies to $\operatorname{ER} \beta$, as well as to $\mathrm{ER} \alpha$, has allowed examination of the protein expression of these genes (Taylor and Al-Azzawi, 2000; Choi et al, 2001; Mann et al, 2001; Miyoshi et al, 2001; Omoto et al, 2001; Roger et al, 2001; Skliris et al, 2001, 2002; Saji et al, 2002; Saunders et al, 2002). One previous report suggested a lack of correlation between mRNA and protein for total ER $\beta$ in 37 out of 61 tumours studied (Shaw et al, 2002). Consequently, there is a lack of available data on the possible significance of $\operatorname{ER} \beta$ expression in specific treatment cohorts. Furthermore, many previous studies have not adequately defined the precise $\operatorname{ER} \beta$ variants being measured or have used antibodies capable of detecting multiple variants (Skliris et al, 2003). The relatively high levels of ER $\beta 1$ protein identified in positive cases may indicate that the PPG5/10 antibody, employed in this study, is among the most sensitive presently available for use in immunohistochemistry (Skliris et al, 2002) with the protocol employed herein (Shaaban et al, 2003a). Using this antibody, we have already confirmed that the level of ER $\beta 1$ detected in normal breast epithelium and in premalignant breast lesions is greater than formerly recognised 
(Shaaban et al, 2003a, b). Therefore, the purpose of this study was to test the hypothesis that comparison of protein expression levels of $\mathrm{ER} \alpha$ and $\mathrm{ER} \beta 1$, together with their respective mRNA levels, in a cohort of postmenopausal primary breast cancer patients treated with surgery and hormonal therapy, would accurately predict the clinical and pathological characteristics of these cancers.

\section{MATERIALS AND METHODS}

\section{Patients}

Patients undergoing treatment for invasive breast cancer during the period 1993-1999 were identified within the archival database of the Department of Pathology at the Royal Liverpool University Hospital, and the Cancer Tissue Bank Research Centre (CTBRC) in the same institution. The study population comprised a group of 167 postmenopausal women treated with surgery either with, or without, radiation treatment (Table 1). All patients received adjuvant hormone therapy but no chemotherapy. For 143 cases, endocrine therapy consisted of adjuvant Tamoxifen only. Since steroid receptor analysis was not routinely performed until 1996, some cases were subsequently found to be ER $\alpha$-negative. All cases were subjected to full histopathological review, by three investigators $\left(\mathrm{PAO}^{\prime} \mathrm{N}, \mathrm{CSF}\right.$ and JPS) according to the UK NHSBSP guidelines (National Coordinating Group for Breast Screening, 1997). Clinical follow-up data, with informed consent, were recorded by retrospective case-note review. Ethical approval for the study was obtained from all relevant bodies.

\section{Immunohistochemistry}

Mouse anti-(human ER $\beta 1$ ) monoclonal antibody PPG5/10 was employed to recognise the ER $\beta 1$ isoform (Serotec Ltd, Kidlington, Oxford, UK). Specificity of the antibody has previously been confirmed by Western blotting in our laboratory (Shaaban et al, $2003 \mathrm{~b}$ ). For the immunohistochemical detection of $\mathrm{ER} \alpha$, a mouse anti-(human $E R \alpha$ ) monoclonal antibody was used (Clone 1D5, Dako Ltd, Ely, Cambridge, UK). Progesterone receptor (PgR) status was measured using a mouse monoclonal anti-PgR antibody (Clone 1A6, Novacastra, Newcastle upon Tyne, UK). Ki67 status was assessed using polyclonal rabbit anti-human Ki67 antibody (Ki67p, Novacastra, Newcastle upon Tyne, UK).

Formalin-fixed and paraffin wax-embedded sections of normal, benign and malignant breast tissues were immunostained for ER $\alpha$ and ER $\beta 1$. The methods were identical to those previously described (Shaaban et al, 2002), but with the addition of an overnight incubation at $4{ }^{\circ} \mathrm{C}$ for the ER $\beta 1$ antibody diluted $(1: 2)$ in Tris buffer ( $\mathrm{pH} 7.2$ ) containing $1 \%(\mathrm{w} / \mathrm{v})$ BSA. Immunostaining for $\mathrm{ER} \alpha$ was performed by incubating sections with the mouse anti$\mathrm{ER} \alpha$ monoclonal antibody for $40 \mathrm{~min}$ at room temperature. Positive and negative controls were included for each antibody and in each batch of staining.

Analysis was restricted to the epithelial component of all tissues. To maximise consistency of scoring, only nuclei having moderate or strong staining were regarded as positive, irrespective of cytoplasmic staining. The percentage of positively stained epithelial cells was calculated as a proportion of the total number of epithelial cells present. For ER $\beta 1$, cases were considered as positive only when more than $20 \%$ of cells were stained, as previously described (Jarvinen et al, 2000; Miyoshi et al, 2001; Shaaban et al, 2003b), although other cutoff values were also tested. In contrast with $\mathrm{ER} \alpha$, there has been no agreement on the cutoff value for defining ER $\beta$ positivity. We chose a cutoff value of $20 \%$ as previously described in the studies by Jarvinen et al (2000) and Miyoshi et al (2001), as well as to be consistent with our previous study (Jarvinen et al, 2000; Miyoshi et al, 2001; Shaaban et al, 2003b). A $10 \%$ cutoff (consistent with that employed in our
Table I Histological, clinical and molecular characteristics of 167 breast cancer cases receiving adjuvant endocrinetreatment but no chemotherapy

\begin{tabular}{|c|c|c|c|}
\hline Characteristic & Group & $n$ & $\%$ \\
\hline Histology & Invasive ductal & $|4|$ & 84 \\
\hline \multirow[t]{2}{*}{$n=167$} & Invasive lobular & 13 & 8 \\
\hline & Other & 13 & 8 \\
\hline Surgery & Wide local excision & 104 & 62 \\
\hline$n=167$ & Mastectomy & 63 & 38 \\
\hline \multirow[t]{2}{*}{ Endocrine therapy } & Tamoxifen adjuvant only & 143 & 86 \\
\hline & Other adjuvant only & 7 & 4 \\
\hline$n=167$ & Primary and adjuvant & 17 & 10 \\
\hline Radiotherapy & No & 89 & 53 \\
\hline$n=167$ & Yes & 78 & 47 \\
\hline Stage & 1 & 38 & 23 \\
\hline \multirow{2}{*}{$n=167$} & $\|$ & 93 & 56 \\
\hline & III & 7 & 4 \\
\hline Grade & I & 26 & 16 \\
\hline \multirow{2}{*}{$n=167$} & $\|$ & 65 & 39 \\
\hline & III & 76 & 46 \\
\hline Size & Up to $2 \mathrm{~cm}$ & 67 & 40 \\
\hline$n=165$ & $>2$ to $5 \mathrm{~cm}$ & 98 & 59 \\
\hline Nodal status & Negative & 73 & 44 \\
\hline$n=167$ & Positive & 64 & 38 \\
\hline \multirow[t]{2}{*}{ Lymphovascular invasion } & Negative & 95 & 57 \\
\hline & Positive & 71 & 43 \\
\hline \multicolumn{4}{|l|}{$n=166$} \\
\hline PgR status & Negative & 84 & 57 \\
\hline$n=147$ & Positive & 63 & 43 \\
\hline Ki67 status & Negative & 72 & 51 \\
\hline$n=142$ & Positive & 70 & 49 \\
\hline $\mathrm{ER} \alpha$ status & Negative & 53 & 33 \\
\hline$n=160$ & Positive & 107 & 67 \\
\hline
\end{tabular}

previous studies) was applied as the conventional criterion to define positive ER $\alpha$ or PgR staining (Sannino and Shousha, 1994). Ki67 was regarded as elevated if $>20 \%$ cells were stained, based on the median expression in this cohort of cases.

\section{Reverse transcription (RT) - PCR analysis}

Total RNA $(5 \mu \mathrm{g})$ was provided by the CTBRC. Following DNAaseI digestion (Gibco), RT was performed in duplicate on $0.5 \mu \mathrm{g}$ of RNA, according to the manufacturers' instructions (Gibco). Reverse transcription reactions incorporated Superscript II Reverse Transcriptase (Gibco), $0.5 \mu$ g Oligo (dT) $)_{12-18}$ and $0.5 \mu \mathrm{l}$ Prime Recombinant Ribonuclease Inhibitor (Eppendorf). Parallel reactions were performed in which the RT enzyme was omitted and these acted as controls for genomic DNA contamination. Polymerase chain reactions were performed in $20 \mu \mathrm{l}$ duplicate volumes in 96-well plates, each using $2 \mu \mathrm{l}$ of a $1 / 20$ dilution of cDNA per reaction (equivalent to cDNA from approximately $2.5 \mathrm{ng}$ of total RNA). All PCR reactions included $0.2 \mathrm{mM}$ dNTPs, $0.5 \mathrm{U}$ of HotstarTaq DNA polymerase (Qiagen) and $1 \times$ PCR buffer (containing $1.5 \mathrm{mM} \mathrm{MgCl}$, Qiagen). Oligonucleotide primers for RT - PCR and the conditions used are shown in Table 2 and have been previously validated (Moore et al, 1998; Kurebayashi et al, 2000). Primer concentrations and final $\mathrm{MgCl}_{2}$ concentrations varied according to Table 2. The PCR reaction used for $\operatorname{ER} \beta$ is specific for the ER $\beta 1$ isoform (Moore et al, 1998). $\beta$-Actin and hypoxanthine ribosyltransferase (HPRT) were used as control genes to determine RNA integrity and RT efficiency. Care was taken to ensure that each PCR reaction was limited in cycle number, thus to avoid the plateau phase of the reaction. Oestrogen receptor $\alpha$ RNA was assessed both by ER $\alpha$ PCR and duplex PCR for $\mathrm{ER} \alpha$ and actin primers (Kurebayashi et al, 2000). The data were 
Table 2 Primer sequences, conditions, and product sizes in base pairs (bp) for RT-PCR

\begin{tabular}{|c|c|c|c|c|}
\hline PCR & Primer sequence & [Primer] $(\mu \mathrm{M})$ & {$\left[\mathrm{MgCl}_{2}\right](\mathrm{mM})$} & Size (bp) \\
\hline$\beta$-actin & $\begin{array}{l}\text { TGACGGGGTCACCCACACTGTGCCCATCTA } \\
\text { CTAGAAGCATTTGCGGTGGACGATGGAGGG }\end{array}$ & 0.48 & 1.5 & 610 \\
\hline HPRT & $\begin{array}{l}\text { CTATTGTAATGACCAGTCAACAGGGG } \\
\text { AACTCAACTTGAACTCTCATCTT }\end{array}$ & I & 3 & 367 \\
\hline
\end{tabular}

Table 3 Conditions of sequence-specific PCR cycling reactions

\begin{tabular}{lcccc}
\hline & & \multicolumn{3}{c}{ Condition } \\
\cline { 3 - 5 } & & $\begin{array}{c}\text { Denaturation } \\
\text { phase }\end{array}$ & $\begin{array}{c}\text { Annealing } \\
\text { phase }\end{array}$ & $\begin{array}{c}\text { Extension } \\
\text { phase }\end{array}$ \\
\hline OR $\alpha$ and $\beta$-actin & 35 & $94^{\circ} \mathrm{C}, 15 \mathrm{~s}$ & $58^{\circ} \mathrm{C}, 15 \mathrm{~s}$ & $72^{\circ} \mathrm{C}, 30 \mathrm{~s}$ \\
ER $\beta$ I & 40 & $94^{\circ} \mathrm{C}, 30 \mathrm{~s}$ & $64^{\circ} \mathrm{C}, 40 \mathrm{~s}$ & $72^{\circ} \mathrm{C}, 45 \mathrm{~s}$ \\
HPRT & 36 & $94^{\circ} \mathrm{C}, 30 \mathrm{~s}$ & $60^{\circ} \mathrm{C}, 60 \mathrm{~s}$ & - \\
\hline
\end{tabular}

highly concordant (Chi-square, $P<0.001)$. Polymerase chain reactions for $\operatorname{ER} \beta$, actin and HPRT were performed individually.

Positive controls using MCF-7 cell line cDNA for ER $\alpha$ and testis cDNA for ER $\beta 1$ were included together with negative controls in each reaction plate. Polymerase chain reaction was performed using Perkin-Elmer 9600 thermal cyclers. All cycling reactions were preceded by a pre-incubation at $94^{\circ} \mathrm{C}$ for $13 \mathrm{~min}$, and were followed within a $3 \mathrm{~min}$ final extension at $72^{\circ} \mathrm{C}$. Cycling conditions for reactions are given in Table 3.

Polymerase chain reaction products were separated by electrophoresis on gels containing 2.5\% Seakem Agarose (Flowgen) and TAE buffer ( $40 \mathrm{~mm}$ Tris acetate, $1 \mathrm{~mm}$ EDTA, pH 7.6). Molecular weight markers (PhiX174/HaeIII, Abgene) were included on each gel and DNA was visualised by inclusion of $0.5 \mu \mathrm{g} \mathrm{ml}^{-1}$ ethidium bromide, scanning with a Molecular Dynamics FluorimagerSI and analysis with ImageQuant version 4.1 software (Molecular Dynamics).

The identity of PCR products was confirmed by direct sequencing using DYEnamic ET Dye Terminator Cycle Sequencing Kit for MegaBACE (Amersham Pharmacia Biotech) and analysed on a MegaBACE 1000 (Molecular Dynamics). Alternatively, PCR products were cloned using TOPO-TA cloning (Invitrogen) prior to sequence analysis.

The presence of a PCR product was assessed independently by two investigators ( $\mathrm{PAO}^{\prime} \mathrm{N}$ and $\mathrm{MPAD}$ ) and scored as positive where both agreed. Control genes, actin and HPRT were scored as weak or strong positive and individual RT reactions excluded from ER assessment if either gene was negative, or if both were only weak. Cases were considered positive for $\operatorname{ER} \alpha$ or $\operatorname{ER} \beta$ if any band was seen regardless of the intensity.

\section{Statistical analysis}

All statistical analyses were performed using the SPSS ${ }^{\circledR}$ package (Windows, v.11). To compare the immunohistochemical percentage values for $\mathrm{ER} \alpha, \mathrm{PgR}$, Ki67 or ER $\beta 1$ in different groups, data were analysed by the nonparametric, two-sided Mann-Whitney test and the two-sided T-test. The nonparametric, two-sided Mann - Whitney test was also used for other ordinal data such as stage and grade. Association between categorical data was assessed by the Chi-squared test and correlations between interval data were tested using Pearson's correlation coefficient. Survival curves were generated using the Kaplan-Meier method for censored data and compared using the log-rank test. Cox's regression models were used for multivariate survival analysis.

\section{RESULTS}

\section{RT - PCR}

The identities of representative RT-PCR products for each gene were confirmed by sequence analysis. No evidence of artefactual PCR products due to genomic DNA contamination was identified. An example of RT - PCR analysis is shown in Figure 1. The use of control genes $\beta$-actin and HPRT identified 127 cases in which cDNA was considered to be of appropriate quantity and integrity for further analysis. The results of these two control genes were in agreement (Chi-square 27, $P<10^{-6}$ ). Reverse transcription-PCR analysis categorised $66 \%$ cases as $\mathrm{ER} \alpha$-positive and $68 \%$ cases as ER $\beta 1$-positive (Table 4 ). In all, $51 \%$ were positive for both ER $\alpha$ and $\operatorname{ER} \beta 1,18 \%$ negative for both, $17 \%$ positive only for $\operatorname{ER} \alpha$ and $14 \%$ positive only for ER $\beta 1$. There was some association between RT PCR results for each ER (Chi-square 12.3, $P<0.0005)$. The distribution of $\operatorname{ER} \beta$-positive tumours was significantly different between ER $\alpha$-positive and -negative cases.

\section{Immunohistochemistry}

Immunostaining for ER $\alpha$ was performed on 149 cases and was nuclear in all cases regarded as positive. Cytoplasmic-only staining was excluded. Cytoplasmic staining for $\operatorname{ER} \beta$ has been described in several studies and is likely to be genuine and not a staining artefact, although the precise significance of cytoplasmic staining remains unknown. Similar to $\mathrm{ER} \alpha$, cytoplasmic staining without nuclear expression was considered negative, so that only nuclear expression was interpreted as positive to maintain convention and comparability with previously reported studies. Using a cutoff value of $10 \%, 49$ cases (33\%) were ER $\alpha$-negative by immunohistochemistry and the remaining 100 cases $(67 \%)$ classed as ER $\alpha$ positive. Oestrogen receptor $\alpha$ status was available for a further 11 cases by case-note review (Table 1). Conventionally, the epithelial component only was scored on assessing $\operatorname{ER} \alpha$ and $\operatorname{ER} \beta$ positivity. Oestrogen receptor $\alpha$ was expressed in the epithelial cells, but $\operatorname{ER} \beta$ was also expressed in the stroma.

Immunostaining for ER $\beta 1$ was performed on 138 cases. Epithelial cells were considered positive if nuclear staining was identified (Figure 2). Cytoplasmic staining co-existent with nuclear staining was identified in 64 cases (Figure 2). In contrast with $E R \alpha$, there has been no agreement on the cutoff value for defining $\operatorname{ER} \beta$ positivity. The conventional cutoff value for $\mathrm{ER} \alpha$ positivity is $10 \%$ (Sannino and Shousha, 1994). We used a cutoff value of $20 \%$ as 

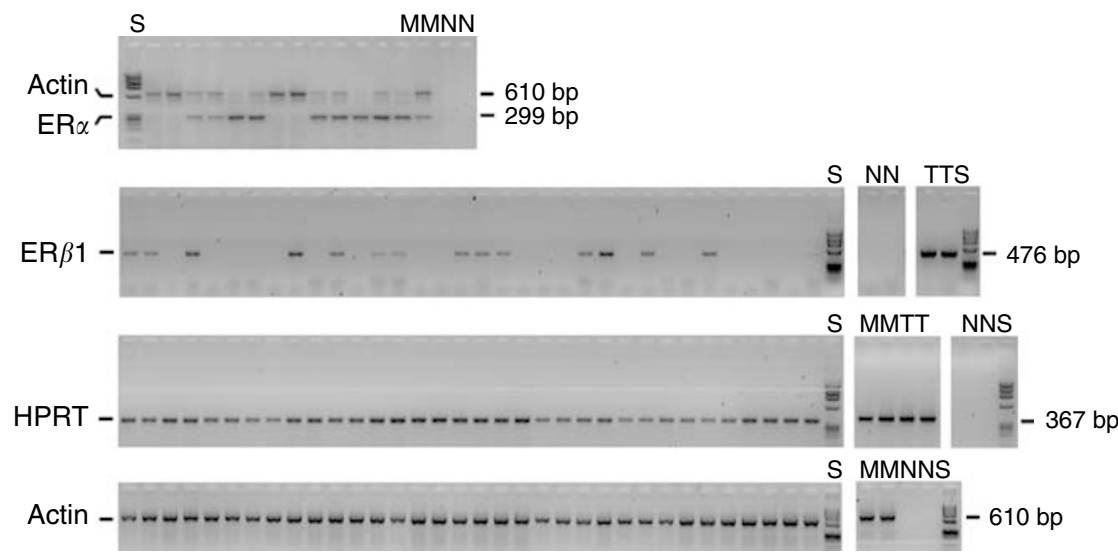

Figure I Reverse transcription-PCR analysis of ER $\alpha, E R \beta$, actin and HPRT. Oestrogen receptor $\alpha$ and actin PCR were performed as a duplex (top) and all other PCRs as single reactions. Controls included were cDNA negative reactions (N), MCF-7 cDNA (M) and testis cDNA (T). All samples were run on agarose gels with PhiX 174/Haelll DNA size markers (S).

Table 4 Relationships between ER $\alpha$ and $E R \beta \mid$ as assessed by immunohistochemistry (IHC) and RT-PCR

ER $\alpha$ IHC

\begin{tabular}{lcccc} 
A & & neg. & pos. & Chi-square (P) \\
\hline$E R \beta \mid I H C$ & neg. & 4 & 16 & 77
\end{tabular}

\begin{tabular}{|c|c|c|c|c|}
\hline B & & \multicolumn{2}{|c|}{$E R \propto R T-P C R$} & Chi-square $(P)$ \\
\hline \multirow[t]{2}{*}{$E R \alpha I H C$} & neg. & 33 & 12 & $47(<0.0005)$ \\
\hline & pos. & 9 & 67 & \\
\hline & pos. & 21 & 65 & \\
\hline \multirow[t]{2}{*}{$\mathrm{ER} \beta \mid \| \mathrm{HC}$} & neg. & 3 & 8 & $0.23(0.64)$ \\
\hline & pos. & 31 & 59 & \\
\hline
\end{tabular}

\begin{tabular}{|c|c|c|c|c|}
\hline \multirow[b]{2}{*}{ C } & & \multicolumn{2}{|c|}{ ER $\beta \mid R T-P C R$} & \multirow[b]{2}{*}{ Chi-square (P) } \\
\hline & & neg. & pos. & \\
\hline$E R \alpha$ status & neg. & 20 & 25 & $4.9(0.027)$ \\
\hline \multirow[t]{2}{*}{$\mathrm{ER} \beta \mid \| \mathrm{HC}$} & neg. & 4 & 7 & $0.08(0.78)$ \\
\hline & pos. & 29 & 61 & \\
\hline
\end{tabular}

previously used in the studied by Jarvinen et al (2000) and Miyoshi et al (2001), as well as to be consistent with our previous study (Shaaban et al, 2003b). The 20\% cutoff (Jarvinen et al, 2000; Miyoshi et al, 2001; Shaaban et al, 2003b) for ER $\beta 1$ staining resulted in a high proportion of positive cases (85\%, 118 cases). The mean percentage of stained cells was $14 \%$ for negative cases and $69 \%$ for positive cases ( $T$-test, $P<0.0005$ ). The proportion of immunostained cancer cells was considerably more variable for $\mathrm{ER} \beta 1$ than for ER $\alpha$ (Figure 3).

Immunohistochemical data for both $\operatorname{ER} \alpha$ and $\operatorname{ER} \beta 1$ were available for 137 cases. In all, $56 \%$ of all cases were positive for both ERs (Table 4) and only 3\% were negative for both ER $\alpha$ and ER $\beta 1$. However, a significant proportion (29\%) was negative for $\mathrm{ER} \alpha$ but expressed ER $\beta 1$, compared to a smaller number of cases expressing ER $\alpha$ alone (12\%). There was no significant association between $\operatorname{ER} \alpha$ and $\operatorname{ER} \beta 1$ status (Chi-square 1.6, $P=0.21$ ). No correlation between the proportion of immunopositive cells was identified (Pearson's $R=-0.007, P=0.94$ ).

\section{Relationship between ER RT - PCR and immunohistochemistry}

Reverse transcription-PCR for ER $\alpha$ was performed on 121 cases with known ER $\alpha$ immunohistochemistry status. There was a significant association between the two techniques (Chi-square 47, $P<0.0005)$. For ER $\alpha$ RT - PCR-negative cases, the median expression of ER $\alpha$ by immunohistochemistry was zero. For ER $\alpha$ RT PCR-positive cases, median expression of $\mathrm{ER} \alpha$ by immunohistochemistry was $90 \%$ (Figure 3). The proportion of immunostained cells was significantly higher in cases positive for ER $\alpha$ by RT - PCR (both $T$-test and Mann-Whitney $P<0.0005)$.

Both RT-PCR and immunohistochemistry were assessed for ER $\beta 1$ in 101 cases (Table 4). No significant relationship was identified between RT-PCR and immunohistochemistry (Chi-square $0.8, P=0.78$ ). This was true for all ER $\beta 1$ immunohistochemical cutoffs tested. There was no significant association between ER $\alpha$ RT-PCR and ER $\beta 1$ immunohistochemistry 

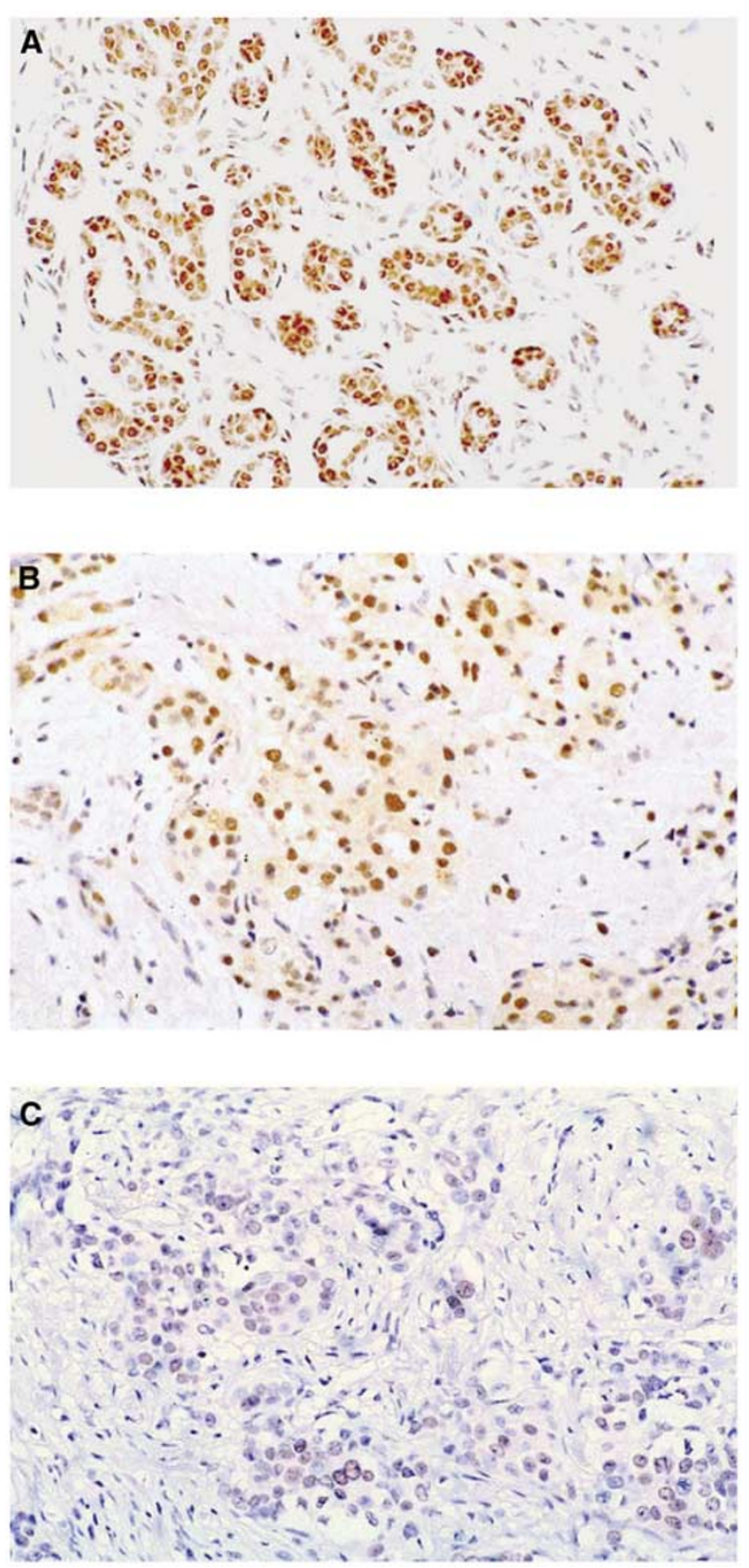

Figure 2 Immunohistochemical staining with $E R \beta \mid$ antibody. In normal breast $(\mathbf{A})$, a strong nuclear staining of the majority of luminal cells is seen and the myopeithelial cells and stromal cells also express the protein Examples of invasive ductal carcinoma of no special type show either strong nuclear expression with some cytoplasmic staining $(\mathbf{B})$ or staining of only a few positive cells $(\mathbf{C})$.

(Chi-square $0.23, P=0.64$ ); although there was an association between ER $\beta 1$ RT-PCR and positive ER $\alpha$ immunohistochemical status (Chi-square 4.0, $P=0.027$ ), the mean $\mathrm{ER} \alpha$ scores were not significantly different in ER $\beta 1$ RT-PCR-negative and -positive cases (45 and 55\%, respectively, $T$-test $P=0.25$ ).

\section{Relationship between ER immunohistochemistry and other parameters}

Oestrogen receptor $\alpha$ expression, determined by immunohistochemistry, was associated with PgR status and Ki67 status (Table 5). Mean PgR staining was significantly higher in ER $\alpha$ -
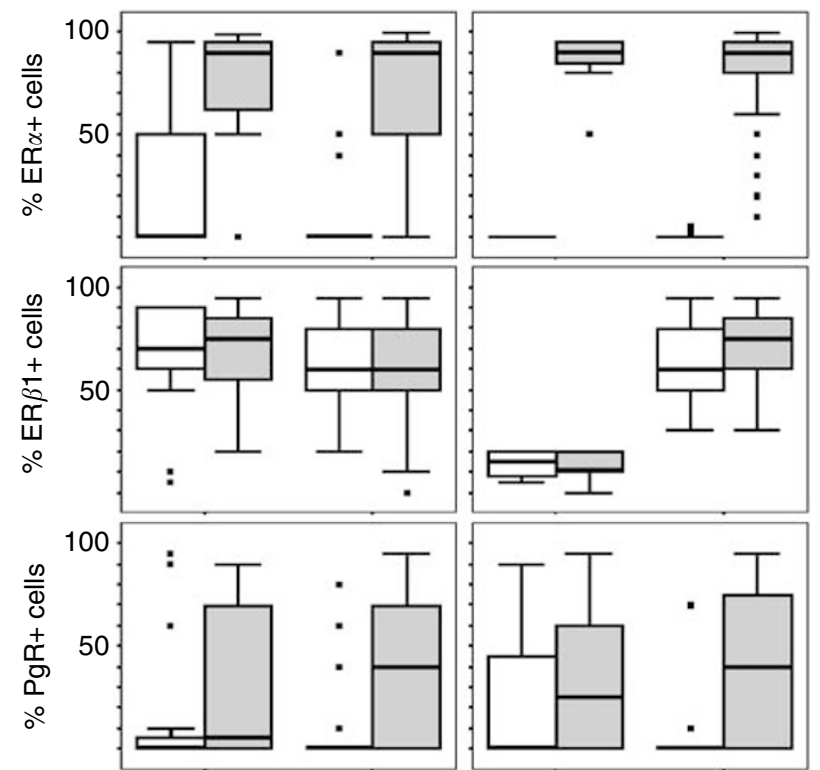

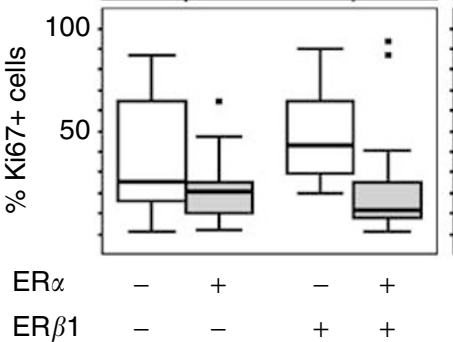

Status by RT-PCR

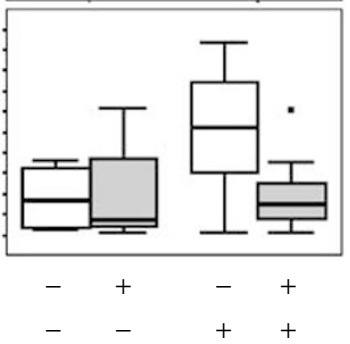

Status by IHC
Figure 3 Boxplots of immunohistochemistry data (\% immunopositive cells) for $E R \alpha, E R \beta I, P g R$ and Ki67 categorised by RT-PCR results (left) or $\| H C$ results (right) for $E R \alpha$ and $E R \beta \mid$. The box represents the interquartile range, the line across the box indicates the median and the whiskers extend from the box to the highest and lowest values (excluding outliers and extreme points). Square, black markers represent outliers and extreme points.

positive cases (37 vs 4.7\%, T-test $P<0.0005$ ), while the mean Ki67 was significantly lower (16 vs $47 \%$, $T$-test $P<0.0005$ ). Positive ER $\alpha$ status was also associated with low-stage, low morphological grade and negative nodal status. No association between ER $\alpha$ status and tumour size or lymphovascular invasion was revealed.

No significant association was detected between ER $\beta 1 \mathrm{immu-}$ nohistochemical expression and grade of tumour, axillary nodal status, ER $\alpha$ status or PgR status. There was an association with greater proliferation, measured by Ki67 staining. The mean \% Ki67-positive cells was greater ( $T$-test $P=0.043$ ) in the $\operatorname{ER} \beta 1$ positive cases $(28 \%)$ than in the ER $\beta 1$-negative cases $(18 \%)$. This was true even when considering ER $\alpha$-negative cases, but not ER $\alpha$ positive cases; Ki67 is greater ( $T$-test $P=0.022$, Mann-Whitney $P=0.028$ ) in $\mathrm{ER} \beta 1$-positive/ER $\alpha$-negative cases (mean $51 \%$ ) than in $\operatorname{ER} \beta 1$-negative/ER $\alpha$-negative cases (mean $18 \%$ ). Using a median cutoff of $60 \%$ (but not a cutoff at $20 \%$ ), there was a trend for the presence of lymphovascular invasion and larger tumours in $\operatorname{ER} \beta 1$ positive cases, as seen for RT-PCR.

\section{Relationship between ER RT - PCR and other parameters}

While there was no relationship between ER $\beta 1 \mathrm{RT}-\mathrm{PCR}$ status and Ki67 staining and only a trend for an association with PgR, there was an association (Figure 4, Table 5) between these parameters and $\mathrm{ER} \alpha \mathrm{RT}-\mathrm{PCR}$ status. Oestrogen receptor $\alpha$ RT-PCR-positive 
Table 5 Relationship between $\mathrm{ER} \alpha, \mathrm{ER} \beta$ and other histopathological variables

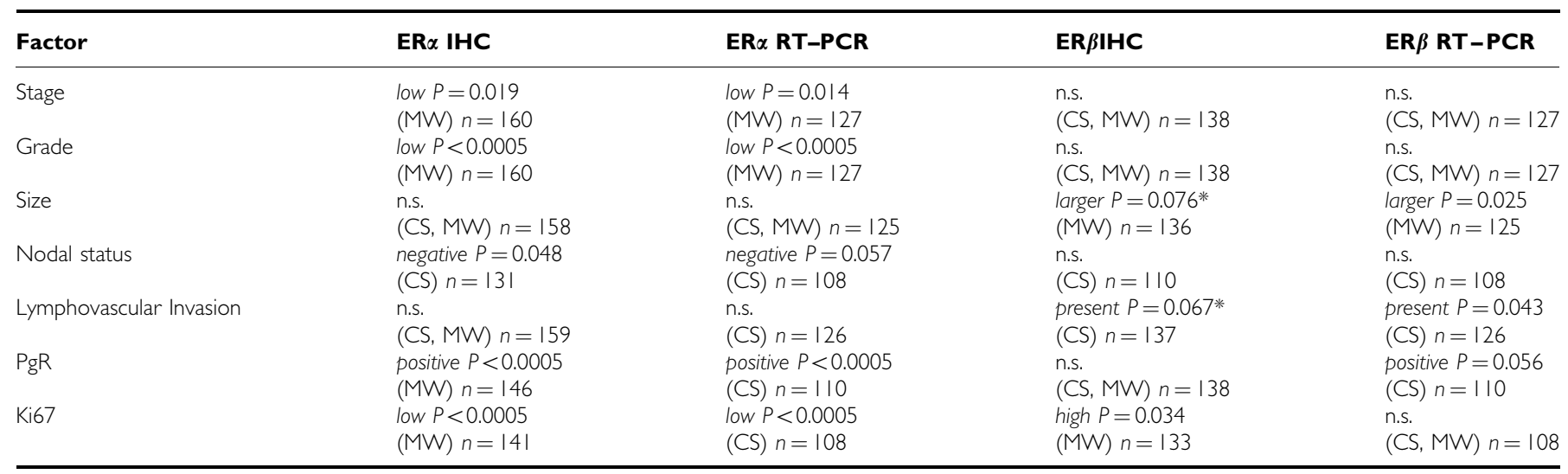

Statistical test used was chi-square (CS), Mann-Whitney (MW); n.s. = not significant. *using a cut-off of $60 \%$ positive cells for ER $\beta$ I.
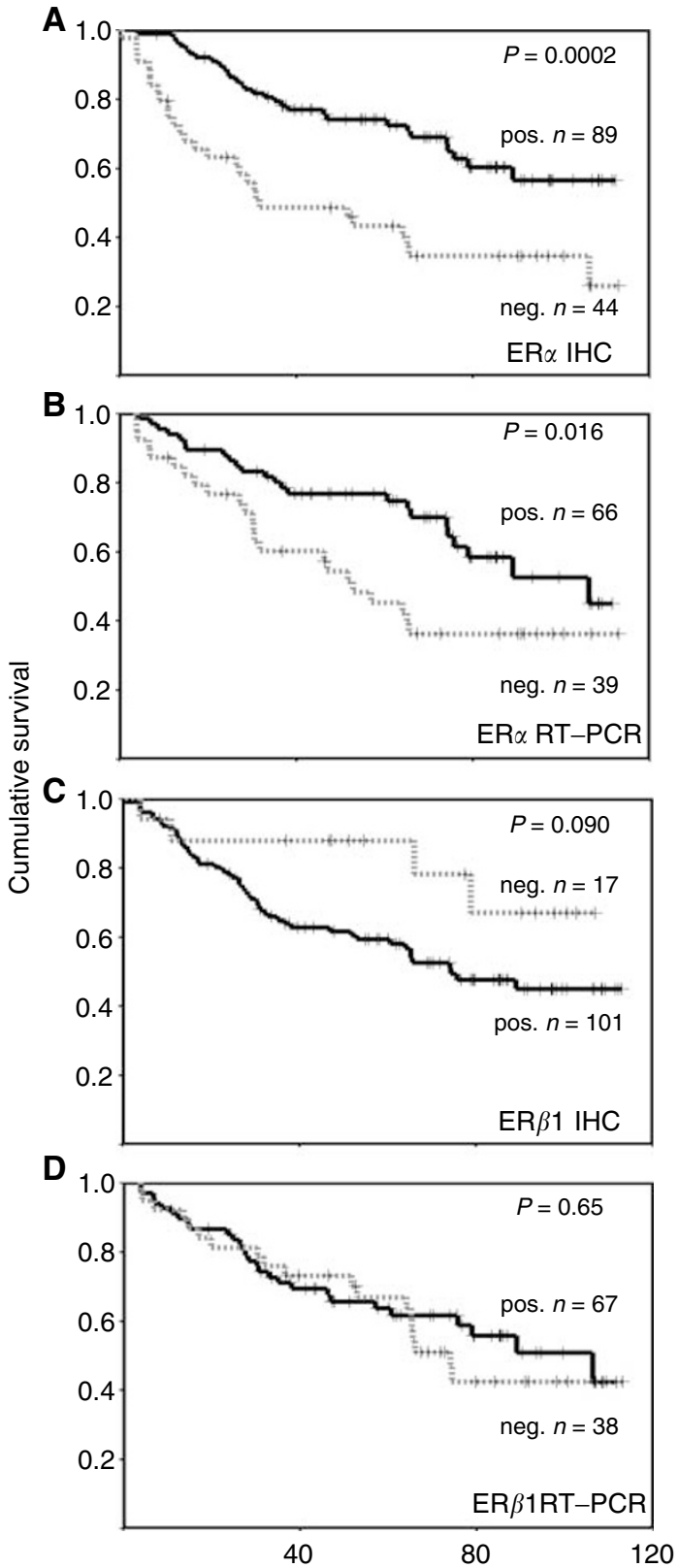

Follow-up (months) status was associated with a significantly higher mean PgR staining (36\% compared to $13 \%$ in negative cases, $T$-test $P<0.001, n=110$ ) and lower mean Ki67 (19\% compared to $41 \%$ in negative cases, $T$ test $P<0.0005, n=109$ ). The relationships between ER $\alpha$ RT-PCR and either PgR or Ki67 remain largely unchanged (Figure 3), irrespective of ER $\beta 1$ RT-PCR status, although Ki67 levels are somewhat higher in $\mathrm{ER} \beta 1$-positive/ER $\alpha$-negative cases. As expected from their ER $\alpha$ status, such tumours had significantly higher Ki67 values and lower PgR values than either ER $\alpha$-positive subgroup ( $T$-test $P<0.04$, Mann-Whitney $P<0.007$ ), but values for these markers were not significantly different from the ER $\beta 1$ negative/ER $\alpha$-negative subgroup (T-test and Mann-Whitney $P>0.08)$.

Demonstration of ER $\alpha$ expression by RT - PCR was significantly associated with low stage and low grade. There was a trend with nodal status, but no association with size or lymphovascular invasion. No relationship between ER $\beta 1 \mathrm{RT}$ - PCR and stage, grade or nodal status was identified, although associations with lymphovascular invasion and larger tumours were detected (Table 5).

Cases that were ER $\beta 1$-positive/ER $\alpha$-negative by RT-PCR had larger tumours (mean $4.1 \mathrm{~cm}$ ) than those that were ER $\beta 1$-positive/ ER $\alpha$-positive $(2.7 \mathrm{~cm}, T$-test $P<0.0005), \mathrm{ER} \beta 1$-negative/ER $\alpha$-negative $(2.2 \mathrm{~cm}, T$-test $P=0.001)$ or $\mathrm{ER} \beta 1$-negative/ER $\alpha$-positive $(3.1 \mathrm{~cm}$, Mann-Whitney $P=0.012)$. These $\operatorname{ER} \beta 1$-positive $/ \mathrm{ER} \alpha$ negative tumours were also of higher stage than the other three subgroups defined by RT - PCR (Mann - Whitney $P<0.017)$.

\section{Relationship between ER and disease outcome}

In order to examine the possible effect of ER $\beta 1$ status in a cohort of patients receiving the same endocrine treatment, outcome data have been restricted to those 143 women receiving adjuvant Tamoxifen, but without primary endocrine treatment and no primary or adjuvant chemotherapy. In this cohort, $\mathrm{ER} \alpha$ expression determined by immunohistochemistry (Figure 4), stage, grade, size, nodal status, Ki67 staining and PgR were all associated with the expected manner that measures of breast cancer relapse-free survival (RFS) and demonstrated significant differences in breast cancer-associated survival (BCS) and overall survival (OS). All these markers had significant log-rank scores for RFS, BCS and OS (all log-rank $P<0.021$ ). Lymphovascular invasion only exhibited a

Figure 4 Kaplan-Meier RFS curves for $E R \alpha$ status (A), ER $\alpha$ RT-PCR (B), ER $\beta|| H C(\mathbf{C})$ and $E R \beta \mid R T-P C R(\mathbf{D})$. Dotted lines are negative cases and unbroken lines positive cases, crosses represent censored data, $P$ values are given for log-rank tests. 
trend for poorer outcome ( $P=0.08$ for RFS, $P=0.09$ for BCS). In multivariate analysis, $\mathrm{ER} \alpha$ immunohistochemistry status was independently significant for RFS in the presence of each other parameter apart from grade and Ki67 status. Considering multiple parameters, the strongest significance was attached to nodal status, followed by grade.

Positive ER $\alpha$ immunohistochemical scores were associated with better RFS using all cutoff points from the standard 10-90\% positive cells $(P<0.001)$. Positive ER $\alpha$ RT-PCR status was associated with a better outcome, as measured by RFS (Figure 4), but not BCS $(P=0.055)$ or OS $(P=0.21)$. No significant association with outcome was seen for ER $\beta 1$ RT - PCR (Figure 4; $P=0.65$ RFS, $P=0.27$ BCS, $P=0.87$ OS). There was a trend for better survival in cases immunohistochemically negative for $\operatorname{ER} \beta 1$ (Figure $4 \mathrm{C}$ ). Only four of the $17(24 \%)$ ER $\beta 1$-negative cases relapsed, when compared to 51 of 103 (50\%) ER $\beta 1$-positive cases (Fisher's exact test, $P=0.029$ ). This was not true for any other cutoff tested.

Within the adjuvant Tamoxifen cohort, 91 cases were ER $\alpha$ positive by immunohistochemistry and therefore typical of those women who are likely to receive adjuvant endocrine treatment today. Within this subgroup grade, nodal status and Ki67 were all significant markers of outcome (RFS, BCS and OS all log-rank $P<0.01$ ), as were stage (RFS log-rank $P<0.01$, BCS $P=0.03$ ), PgR (BCS, RFS and OS all log-rank $P<0.05$ ) and size (OS log-rank $P=0.015)$. ER $\beta 1$ RT-PCR showed no association with any measure of outcome, but as before a trend for a worse outcome in ER $\beta 1$ immunohistochemically positive cases was seen (RFS, logrank $P=0.11$; Fisher's exact test, $P=0.061$ )

\section{DISCUSSION}

This study has confirmed the initial hypothesis that comparison of protein expression levels for $\operatorname{ER} \alpha$ and $\operatorname{ER} \beta 1$, together with their respective mRNA levels, are indicators of the clinical and pathological characteristics of a cohort of postmenopausal primary breast cancer patients treated only surgically and thereafter with Tamoxifen therapy. The findings confirm the differential expression of these two oestrogen receptors by human breast carcinomas, with a high degree of correlation between the immunohistochemical and RT-PCR data for ER $\alpha$ being identified.

Unlike the findings for $\mathrm{ER} \alpha$, this study did not reveal a strong correlation between ER $\beta$ RT-PCR and the corresponding immunohistochemistry. Identification of the technical and biological reasons for this apparent discrepancy is of fundamental importance to understanding the role of $\operatorname{ER} \beta$ in human breast cancer. Recently, Omoto et al (2002) reported that protein and RNA levels are often not in agreement, but did not provide any cogent explanation for this discrepancy. Three potentially important factors require consideration: First, this apparent discrepancy might be explained by relative lack of sensitivity of RT - PCR when compared to the $20 \%$ immunohistochemical cutoff (where $29 \%$ of cases were RT-PCR negative and immunohistochemically positive). Previously, it has been reported that mRNA levels for $\operatorname{ER} \beta$ are lower and more diverse than those for ER $\alpha$ (Iwao et al, 2000) and that levels of $\operatorname{ER} \beta 1$ are lower than for other $\operatorname{ER} \beta$ variants (Leygue et al, 1999; Iwao et al, 2000). Either of these phenomena would contribute to a lower sensitivity for detection of ER $\beta 1$ by RT - PCR. When testing for a possible correlation between ER $\beta 1$ identified by RT-PCR and by immunohistochemistry, various cutoff levels were assessed. However, there was no value that gave a statistically significant association with the RT-PCR data. In contrast, correlations occurred between ER $\beta 1$ RT-PCR and with both ER $\alpha$ immunohistochemistry and RT-PCR, which were not recapitulated at the protein level and which would account for other reports of relationships between the two ERs. Second, while immunohistochemistry is an in situ technique in which data are obtained subjectively, RT - PCR is performed on disaggregated tissue preparations in a quantitative manner. Hence, expression of ER $\beta 1 \mathrm{mRNA}$ from other cell types might account for the seven cases that were RT-PCR positive and immunohistochemically negative, but not the 29 RT-PCR-negative but immunohistochemically positive cases. While a theoretical possibility, this explanation is interesting since nonepithelial stromal cells of normal breast tissues have been found to be weakly $\operatorname{ER} \beta$ positive while stromal cells of the unusual phylloides tumours were found to strongly express ER $\beta$ (Shaaban et al, 2003b).

Translational or post-translational control mechanisms are likely to play a significant role in $\operatorname{ER} \beta$ expression in some cases of breast cancer. We have already shown that modulation of ERs is both complex and indirect, the latter mechanisms including altered expression of homeostatic protein hsp-27 (O’Neill et al, 2003). It is now recognised that the precise structure of many proteins expressed by individual genes varies with the phenotypic status of an individual cell. These 'splice variants', while encoded within the normal genome, become expressed according to the overall status of the tissue in which they originate (e.g. embryonic, adultproliferative or malignant). Such differences are already recognised to be important, with respect to splice variants of some proteins (e.g. voltage-gated ion channels), but are yet to be proven for others (e.g. ERs), although there is substantial circumstantial evidence for this selection. If splice variation is an important factor in the expression of $\mathrm{ER} \beta$, then use of monoclonal antibodies directed to epitopes in the wild type that become spliced out and hence nonexpressed in the cancers provide erroneous information. Recognition of this caveat is important for accurate interpretation of such data. Multiple forms of $\operatorname{ER} \beta$ splice variants occur in normal breast tissue and breast malignancies (Leygue et al, 1999; Omoto et al, 2002). Unfortunately, most previous RT-PCR analysis studies have used primers unsuitable for distinguishing individual isoforms. Recent production of antibodies suitable for detection of individual ER $\beta$ isoforms (Saunders et al, 2002; Skliris et al, 2002) should allow a better understanding of the complex factors regulating hormone responsiveness of human breast carcinomas to emerge (O'Neill et al, 2003; Shaaban et al, 2003b).

In the current series, and in accordance with previous immunohistochemical reports (Enmark et al, 1997), ER $\beta 1$ was predominantly localised to the nuclei of epithelial cells and of myoepithelial cells, as well as stromal cells (Taylor and Al-Azzawi, 2000; Speirs et al, 2002). Oestrogen receptor $\beta 1$ expression was identified in $85 \%$ of invasive cancers using a $20 \%$ immunohistochemical cutoff and the median expression was $60 \%$. The reported proportion of ER $\beta 1$-positive invasive carcinomas varies appreciably among previous studies and might be explained by differences in the specificity of the antibodies, methods of antigen retrieval and different thresholds used to define positive staining (Skliris et al, 2002; Shaaban et al, 2003a). In the current cohort, $56 \%$ of cancers were positive for both $\operatorname{ER} \alpha$ and $\operatorname{ER} \beta 1$ by immunohistochemistry, while $29 \%$ of cancers were ER $\alpha$-negative and $\operatorname{ER} \beta 1$ positive. Given the potential discrepancies due to antibody usage and staining technique, together with the robust levels of $\operatorname{ER} \beta 1$ staining, these numbers are in agreement with those reported in other immunohistochemical studies of ER $\beta 1$ (Jarvinen et al, 2000; Omoto et al, 2002; Saunders et al, 2002), which describe $48-74 \%$ of cases as $\mathrm{ER} \beta 1$-positive/ER $\alpha$-positive and $8-20 \%$ as $\operatorname{ER} \beta 1$ positive/ER $\alpha$-negative. Unlike $\mathrm{ER} \alpha$, which is usually expressed in only a minority of cells in normal epithelium and aberrantly expressed at high levels in the majority of cells in many breast cancers, ER $\beta 1$ is apparently expressed in the majority of cells in normal breast and this expression is maintained in most breast cancers at a variety of levels. Persisting but varied expression of $\operatorname{ER} \beta 1$ in the presence or absence of greater amounts of ER $\alpha$ indicates that the role played by the interaction between $\mathrm{ER} \alpha$ and ER $\beta 1$ during mammary carcinogenesis and in subsequent cancers is likely to be complex. Thus, this study has pinpointed a cellular 
control mechanism that, in human breast cancer, requires specific and detailed analysis.

Only one previous study has reported ER $\beta$ immunohistochemistry in adjuvant Tamoxifen-treated patients (Mann et al, 2001). In contrast to our present findings, the previous adjuvant study suggested $\operatorname{ER} \beta$-positive patients to have a better survival when compared with $\operatorname{ER} \beta$-negative patients. Overall, the immunostaining reported in the previous study appeared weaker than observed here, with only $66 \%$ of 118 cases being $\operatorname{ER} \beta$-positive at a $10 \%$ cutoff, when compared to $85 \%$ positive for ER $\beta 1$ at a $20 \%$ cutoff. Since that study utilised an antibody with broad specificity, possible contribution of other $\operatorname{ER} \beta$ variants is unclear. It is possible that the findings of that study are due to expression of variants $\operatorname{ER} \beta 2$ and $\operatorname{ER} \beta 5$ since, at the RNA level, these have been shown to be greater than ER $\beta 1$ in breast cancers (Leygue et al, 1999; Omoto et al, 2002). The isoform of $\operatorname{ER} \beta$ to have the greatest effect on outcome for breast cancer patients is yet to be confirmed. Although only seen here for RT - PCR, others have reported some association between $\mathrm{ER} \alpha$ and $\operatorname{ER} \beta$ staining (Jarvinen et al, 2000; Omoto et al, 2001) and it is possible that the unreported $\mathrm{ER} \alpha$ status of the cases previously reported has some influence on the data (Mann et al, 2001). In this study, no association was found between $\operatorname{ER} \beta$ and grade of tumour, progesterone receptor, or nodal status, thus broadly in agreement with other studies. However, in this cohort of post-menopausal women treated with Tamoxifen therapy, $\operatorname{ER} \beta$-positive cancers tended to have poorer RFS than $\operatorname{ER} \beta$-negative cancers. This finding was not entirely due to the presence of $\operatorname{ER} \beta$ in some $\mathrm{ER} \alpha$-negative cases, since a trend was still present in the $\mathrm{ER} \alpha$-positive subgroup.

\section{REFERENCES}

Choi I, Ko C, Park-Sarge OK, Nie R, Hess RA, Graves C, Katzenellenbogen BS (2001) Human estrogen receptor beta-specific monoclonal antibodies: characterization and use in studies of estrogen receptor beta protein expression in reproductive tissues. Mol Cell Endocrinol 181: 139-150

Enmark E, Pelto-Huikko M, Grandien K, Lagercrantz S, Lagercrantz J, Fried G, Nordenskjold M, Gustafsson JA (1997) Human estrogen receptor betagene structure, chromosomal localization, and expression pattern. J Clin Endocrinol Metab 82: $4258-4265$

Iwao K, Miyoshi Y, Egawa C, Ikeda N, Noguchi S (2000) Quantitative analysis of estrogen receptor-beta mRNA and its variants in human breast cancers. Int J Cancer 88: 733-736

Jarvinen TA, Pelto-Huikko M, Holli K, Isola J (2000) Estrogen receptor beta is coexpressed with ERalpha and PR and associated with nodal status, grade, and proliferation rate in breast cancer. Am J Pathol 156: $29-35$

Kurebayashi J, Otsuki T, Kunisue H, Tanaka K, Yamamoto S, Sonoo H (2000) Expression levels of estrogen receptor-alpha, estrogen receptorbeta, coactivators, and corepressors in breast cancer. Clin Cancer Res 6: $512-518$

Leygue E, Dotzlaw H, Watson PH, Murphy LC (1999) Expression of estrogen receptor beta1, beta2, and beta5 messenger RNAs in human breast tissue. Cancer Res 59: 1175-1179

Locker GY (1998) Hormonal therapy of breast cancer. Cancer Treat Rev 24: $221-240$

Mann S, Laucirica R, Carlson N, Younes PS, Ali N, Younes A, Li Y, Younes M (2001) Estrogen receptor beta expression in invasive breast cancer. Hum Pathol 32: 113-1138

Miyoshi Y, Taguchi T, Gustafsson JA, Noguchi S (2001) Clinicopathological characteristics of estrogen receptor-beta-positive human breast cancers. Jpn J Cancer Res 92: 1057-1061

Moore JT, McKee DD, Slentz-Kesler K, Moore LB, Jones SA, Horne EL, Su JL, Kliewer SA, Lehmann JM, Willson TM (1998) Cloning and characterization of human estrogen receptor beta isoforms. Biochem Biophys Res Commun 247: 75-78

National Coordinating Group for Breast Screening (1997) Pathology Reporting in Breast Cancer Screening NHSBSP publication no. 3, Sheffield
This study lends some support to the original hypothesis that expression of wild-type ER $\alpha$ influences the effectiveness of antioestrogen therapy. Furthermore, antioestrogens (e.g. Tamoxifen) of particular affinity for the specific splice variant of oestrogen receptor expressed by each individual breast carcinoma may have agonistic effects in $\operatorname{ER} \beta$-positive tumours, hence resulting in a lack of efficacy of hormonal therapy (Speirs et al, 1999). There is evidence that this might also be true for $\operatorname{ER} \beta 2$, since this protein was associated with poor response to Tamoxifen in a neoadjuvant setting (Saji et al, 2002). However, our data contradict less critical reports that are imprecise with respect to patient groups examined and ER $\beta$ variants detected. Further studies are now being performed to clarify the roles of different $\operatorname{ER} \beta$ splice variants in breast cancers treated by hormonal manipulation. These will include cohorts of patients selected according to clinical and treatment criteria in order to determine the importance of $\operatorname{ER} \beta$ in breast cancer management and outcome.

\section{ACKNOWLEDGEMENTS}

We wish to acknowledge, and are grateful, to the Clatterbridge Cancer Research Trust and the North West Pennine Health Authority (NHS), UK, in supporting this work. Professor John P Sloane (JPS) was instrumental in the initiation of this work, his involvement is respectfully acknowledged. We thank Mr AJC Williams for technical assistance and Mrs JC Gosney for editing the manuscript.

Omoto Y, Inoue S, Ogawa S, Toyama T, Yamashita H, Muramatsu M, Kobayashi S, Iwase H (2001) Clinical value of the wild-type estrogen receptor beta expression in breast cancer. Cancer Lett 163: 207-212

Omoto Y, Kobayashi S, Inoue S, Ogawa S, Toyama T, Yamashita H, Muramatsu M, Gustafsson JA, Iwase H (2002) Evaluation of oestrogen receptor beta wild-type and variant protein expression, and relationship with clinicopathological factors in breast cancers. Eur J Cancer 38: $380-386$

O’Neill PAO, Shaaban AM, West CR, Dodson A, Jarvis C, Moore P, Davies MPA, Sibson DR, Foster CS (2003) Increased risk of malignant progression in benign proliferating breast lesions defined by expression of heat shock protein 27. Br J Cancer 90: $182-188$

Paech K, Webb P, Kuiper GG, Nilsson S, Gustafsson J, Kushner PJ, Scanlan TS (1997) Differential ligand activation of estrogen receptors ER alpha and ER beta at AP1 sites. Science 277: 1508-1510

Pertschuk LP, Axiotis CA (1999) Steroid hormone receptor immunohistochemistry in breast cancer: past, present, and future. Breast J 5: 3-12

Roger P, Sahla ME, Makela S, Gustafsson JA, Baldet P, Rochefort H (2001) Decreased expression of estrogen receptor beta protein in proliferative preinvasive mammary tumors. Cancer Res 61: 2537-2541

Saji S, Omoto Y, Shimizu C, Warner M, Hayashi Y, Horiguchi S, Watanabe T, Hayashi S, Gustafsson JA, Toi M (2002) Expression of estrogen receptor (ER) (beta)cx protein in ER(alpha)-positive breast cancer: specific correlation with progesterone receptor. Cancer Res 62: $4849-4853$

Sannino P, Shousha S (1994) Demonstration of oestrogen receptors in paraffin wax sections of breast carcinoma using the monoclonal antibody 1D5 and microwave oven processing. J Clin Pathol 47: 90-92

Saunders PT, Millar MR, Williams K, Macpherson S, Bayne C, O’Sullivan C, Anderson TJ, Groome NP, Miller WR (2002) Expression of oestrogen receptor beta (ERbeta1) protein in human breast cancer biopsies. $\mathrm{Br} J$ Cancer 86: $250-256$

Shaaban AM, O'Neill P, Foster CS (2003a) Skliris et al. Evaluation of seven oestrogen receptor beta antibodies for immunohistochemistry, western blotting, and flow cytometry in human breast tissue. J Pathol 199: 130

Shaaban AM, O'Neill PA, Davies MPA, Sibson R, West CR, Smith PH, Foster CS (2003b) Declining estrogen receptor beta expression defines 
malignant progression of human breast neoplasia. Am J Surg Path 27: $1502-1512$

Shaaban AM, Sloane JP, West CR, Foster CS (2002) Breast cancer risk in usual ductal hyperplasia is defined by estrogen receptor-alpha and Ki-67 expression. Am J Pathol 160: 597-604

Shaw JA, Udokang K, Mosquera J-M, Chuhan H, Jones JA, Walker R (2002) Oestrogen receptors alpha and beta differ in normal human breast and breast carcinomas. J Pathol 198: 450-457

Skliris GP, Carder PJ, Lansdown MR, Speirs V (2001) Immunohistochemical detection of ERbeta in breast cancer: towards more detailed receptor profiling? Br J Cancer 84: 1095 - 1098

Skliris GP, Munot K, Bell SM, Carder PJ, Lane S, Horgan K, Lansdown MRJ Parkes AT, Hanby AM, Markham AF, Speirs V (2003) Reduced expression of oestrogen receptor beta in invasive breast cancer and its re-expression using DNA methyl transferase inhibitors in a cell line model. J Pathol 201: $213-220$

Skliris GP, Parkes AT, Limer JL, Burdall SE, Carder PJ, Speirs V (2002) Evaluation of seven oestrogen receptor beta antibodies for immunohistochemistry, western blotting, and flow cytometry in human breast tissue. J Pathol 197: 155-162

Speirs V, Malone C, Walton DS, Kerin MJ, Atkin SL (1999) Increased expression of estrogen receptor beta mRNA in Tamoxifen-resistant breast cancer patients. Cancer Res 59: $5421-5424$

Speirs V, Skliris GP, Burdall SE, Carder PJ (2002) Distinct expression patterns of ER alpha and ER beta in normal human mammary gland. J Clin Pathol 55: $371-374$

Taylor AH, Al-Azzawi F (2000) Immunolocalisation of oestrogen receptor beta in human tissues. J Mol Endocrinol 24: 145-155 